Article

\title{
Pray the White Way: Religious Expression in the NFL in Black and White
}

\author{
Jeffrey Scholes \\ Department of Philosophy, University of Colorado Colorado Springs, Colorado Springs, CO 80918, USA; \\ jscholes@uccs.edu
}

Received: 6 July 2019; Accepted: 31 July 2019; Published: 6 August 2019

\begin{abstract}
Athletes, particularly players in the National Football League, have repeatedly invoked God in order to glorify, praise, or even credit the divine with success on the field. This essay examines the ways in which different types of religious language used to bring God onto the gridiron are received and evaluated along racial lines. I seek to show that speech by athletes, in particular black football players, that communicates a God who is partisan and intervenes in action on the field is routinely dismissed by fellow players, the media, and religious authorities who favor a God who either intervenes softly and generally or is above the game altogether. I contend that a double standard is applied to this theological debate due to a disregard of historical African American theology and to hegemonic white evangelical norms that police such discourse.
\end{abstract}

Keywords: race; national football league; religious expression; prayer; black church; providentialism; evangelicalism

\section{Introduction}

David J. Leonard, in his book Playing While White, compares and contrasts the ways that trash-talking in sports is digested and interpreted along racial lines. He finds that white athletes who trash-talk (belittling the opposition to gain an advantage), such as Tom Brady, Peyton Manning, Larry Bird, and Michael Phelps, are praised by the media and fans for this behavior. The talk demonstrates passion and fierce competitiveness rather than a petty or even mean comportment. Alternatively, the trash-talk dished out by black athletes such as Muhammad Ali, Allen Iverson, Serena Williams, and Shannon Sharpe is often deemed disrespectful, uncivil, and a sign of societal decline.

Leonard calls out this glaring double standard for what it is-the amount of melanin in one's skin determines how your trash-talk is received. It is within a protected space that white athletes move and speak, and therefore their trash-talk is at worst "childish" but at best "illegible" for its inability to be translated as truly disrespectful despite the disrespectful language used (Leonard 2017, p. 73). Within the relatively unprotected space that black athletes occupy, where blackness is equated with "criminality", "rage", and harmful hip-hop culture, trash-talking somehow furnishes us with a window into the character of the athletes (Leonard 2017, pp. 66, 69, 84). And that character is putatively damaging the sport and setting a poor example for young fans.

As Leonard chronicles, white quarterback Johnny Manziel during his sophomore year at Texas A\&M pretended to give an autograph to an opposing player after converting a first down and then flashed a "money-counting gesture" throughout the game and in subsequent games. This behavior was taken by some media members as a sign of his "gladiator mentality" and only an indication that Manziel was just "having fun" (Leonard 2017, pp. 76-77). Alternatively, for black cornerback Richard Sherman, the tongue-lashing that he administered on opponent Michael Crabtree after preventing a touchdown received the complete opposite reaction. By some in the media, Sherman was called a thug; was immature, classless and dangerous. His speech-act was characterized as an unprofessional 
tirade and garbage (Leonard 2017, pp. 82-83). Leonard interprets this and other similar situations that he cites as such,

White America is deeply uncomfortable with African American trash-talkers; the sight and sound of black emotion, whether anger or joy, whether frustration or passion, elicits ample reaction, dissection, and commentary. Bravado and confidence, like rage, is unacceptable in association with blackness. Whiteness plus brashness is not only acceptable but also desired and celebrated. (Leonard 2017, p. 84)

Because there is "no mention of the cultural practices of signifying ... no discussion of oral traditions or cultures of resistance" (Leonard 2017, p. 74) that infuse the African American experience and its expression, trash-talk uttered by black athletes is left exposed to appropriation that is largely guided by stereotypes that are applied to blacks and whites with equal measure. Manziel's "whiteness contributed to an alternative reading of his words and his trash-talking swagger", whereas Sherman's language, "reflects the danger seen in black bodies that lack 'discipline, that are not under control"" (Leonard 2017, pp. 75, 86).

I start this essay with the double standard applied to trash-talking to set up a question: is a similar double standard applied to the religious expressions of athletes? Religious expressions such as prayers, statements of thanks, religious gestures, etc., are also considered to be extraneous to sport. These expressions have likewise raised the ire of the media and fans throughout the years. And these kinds of statements or gestures can be bold and brash. I contend that the racialized dual-interpretation of trash-talking is analogous to that of the treatment of religious expressions in the NFL. This double standard is predicated on the assumption that most religious expressions, no matter the race of the player, rely upon the premise that God is active in the world and hence involved in the game of football in some way. The difference between God giving strength to players and giving victories to players is minimal theologically, but apparently vast culturally.

Like trash-talk (or any talk), the religious expressions of professional football players and coaches emerge from cultural contexts that help clarify and even justify the content and style of the expression, whether spoken by white or black players. Yet, the voicing of the conviction that God does intervene in the sport itself, whether held by black or white athletes, is too often abstracted from the historical and political contexts from which they arise respectively often rewarded or conveniently overlooked when uttered by white athletes and dismissed as nonsense or labeled as heterodox or worse when spoken by African Americans with no consideration of the sources

After offering a typology of religious language in the sporting world, I examine the historical and cultural sources that black and white religious expressions rely on. I then turn to several examples of African American football players who use what I call "hard providential" language to articulate their understanding of their play on the field and the critical responses to such language made by white players, media members, and religious authorities. Finally, I look at the way that white evangelical quarterback Tim Tebow relates God to football through a "soft providentialism" that calls on God to give him strength and keep the game injury-free-a theology that enjoys scant notice. Tebow's religious stance is, in part, protected by a double standard that is encouraged by long-standing ideas about race and sustained by white evangelical norms. It can be upheld only when historical and political circumstances that have molded religious expression are disregarded.

\section{Types of Religious Expression in the NFL}

It is estimated that around $40 \%$ of the members of teams in professional baseball, basketball, and football in the United State are evangelicals (Krattenmaker 2010, p. 13). And in a 2016 survey of the players on the NFL's Denver Broncos, $86 \%$ identified as Christian and $90.7 \%$ of those surveyed said that religion "was very important" to them (Klemko 2017). In addition, one-fourth of Americans believe that God directly affects football games, and over half of Americans say that God "rewards athletes who have faith with good health and success" (Cox and Jones 2017). Religious adherence may be waning 
amongst millennials overall in the United States (The Age Gap in Religion around the World 2018), but not so in the sports ranks, particularly with football players and its fans.

There exists a wide range of the types of religious expression in the NFL. Each expression, whether vocal or not, is performative-these athletes and coaches are on a big stage and each utterance is meant to have impact. In addition these expressions have a theology behind them as well, albeit usually unacknowledged nor well developed. A laying out of a brief typology will not only help with a kind of theological categorization but also with the later building of the hierarchical structure that arranges and slots each type into its place along racial lines.

Of course religious expression, like any expression, is the product of complex, often murky sources. Add in the performative component and motive, style, and setting further muddy the water. Moreover, these categories are far from rigid. Many players draw on language found in more than one category-sometimes within the same sentence. Yet as we will see, some types of religious expressions overlap considerably because the theologies and cultural mores undergirding them overlap considerably as well. Where differences are patently evident, it behooves us to ask about the theology within and the authority it is given by a certain culture that makes the expression resonant and/or legitimate with some and not with others.

The sequence of the following typology moves from expressions that convey a God that very lightly intervenes (if at all) in sport to a God who directly interferes with action on the field. The first type, the "it's just a game" type of religious expression, dictates that some things matter much more than sport. When religion is invoked to drive this home, the theology behind it is that God is bigger than football and therefore cares not about play on the field or the outcome. This type of expression does not have to be lodged in a religious context, however. Tony Romo used a version of the phrase after a particularly devastating loss, perhaps as a defensive measure that would minimize the psychological toll. "If this is the worst thing that will ever happen to me, then I've lived a pretty good life" (Curtis 2017).

But for other football players more inclined to locate their game and life in a heavenly context, this kind of statement not only lifts God above the fray, thus safeguarding God's impassibility but also acts as a means of overcoming tough losses, career-ending injuries, and being traded or cut. And if refuge is taken in an impassible divine figure, the troubling vagaries of the game can be relativized in the face of a God who is distanced from sport altogether. This type of religious expression is put nicely by New England Patriots' special teamer, Matthew Slater:

This is not life and death. This is not the biggest thing that we'll do. The biggest and most important decision we'll ever make in our lives is what we do with the knowledge of Jesus Christ. And if you don't know the answer to that question it can be challenging at times. But I think for people that look at this game as the end all, be all, it's not! It's a game. We're thankful to be here, we're thankful for the opportunity. We love what we do but we have to keep perspective on the greater good! (Buehring 2019)

The "billboard" type of religious expression involves God in the game more than the previous type but still relieves the athlete from having to defend the role that God may play in sport. It entails the mere posting of a bible verse or a pithy religious message on a uniform or on social media without commentary. Gestures such as pointing to the sky, making the sign of the cross, kneeling or genuflecting, as quarterback Tim Tebow popularized with his "Tebowing", or "Praise performances", as Shirl Hoffman dubs all of them (Hoffman 1992, p. 157), are functional equivalents to the presentations of a Bible verse. The intent behind them leaves the audience to decipher their meaning. Some of these billboards are hidden but accessible to a few such as the beginning words of Philippians 4:13, "I can do all things ... ", stamped on the inside of the tongue of basketball star Stephen Curry's name-brand 
shoe. ${ }^{1}$ The NFL restricts this kind of messaging far more stringently than does the NBA, ${ }^{2}$ though in 2017, it began to allow approved messages to be shown on players' shoes for a designated week during the season. For example, Philadelphia Eagles' quarterback, Carson Wentz chose to emblazon "AO1" (Audience of One) and "Romans 5:8" in gold caps across the bottom of his cleats.

These standalone displays are largely provocative. After Tebow wore "John 3:16" on his eye black in the 2009 college football championship game, ninety-three million people were provoked to Google the verse. But because the Bible says little about athletic activity and nothing about football, drawing conclusions about the theology of Tebow and why he advertised the verse in this way, aside from the content of the verse, is difficult. One can hide behind the billboard. It will do all of the talking.

The "glorification" type of religious expression centers on individual or team action on and off the field that glorifies God. Almost exclusively inspired by 1 Corinthians 10:31, "So whether you eat or drink or whatever you do, do it all for the glory of God", athletic activity is included in the category of "whatever you do." The act of glorification is performed by an athlete or a coach, but by reflecting God's greatness in the glorifying process, the expression is meant to "give God the glory", not the athlete. These actions are often tangential to the outcome of a game and more tied to how the game is played. Did I play the game ethically? Was sportsmanship demonstrated? Was maximal effort expended? Am I leading by example rather than berating or belittling the opposition? Were emotions channeled in the right direction and therefore not made manifest in foul language or disrespecting the opponent or one's own teammates? If so, then God's qualities were mirrored, and God is thereby glorified in the process.

Sometimes the amount of glory given to God is thought to be amplified on a big stage after a win. Or God is given glory by the performance itself but making sure a large audience knows "the real reason" why one plays the game can bring God even more glory, as Dallas Cowboys' quarterback Roger Staubach iterated after winning the 1972 Super Bowl. "I had promised that it would be for God's honor and Glory, whether we won or lost. Of course the glory was better for God and me since we won, because the victory gave me a greater platform from which to speak" (Blazer 2015, p. 59).

Because it is the actions of the athletes that drive the glorification rhetoric, this type of expression can come off as a kind of humblebrag, as the Seattle Seahawks' quarterback Russell Wilson tweeted after signing a thirty-five million dollar-a-year contract, "My Hallelujah belongs to YOU" followed by the hashtag, \#All For Your Glory. This kind of statement at once is intended to deflect attention away from his own role in securing the contract while the dollar amount shines the light back on Wilson, who is in the process of glorifying God through his success (Parke 2019). One way around this accusation is to emphasize that glorification occurs not through the behavior that reflects God's will, but rather that God's glory is made manifest through a receptive, though imperfect container. For athletes that may possess less raw talent than others, this "vessel" metaphor is more efficacious theologically and culturally than the "mirror."

The last two types of religious expressions involve a God who intervenes the game more directly. The first "soft providential" type and the second "hard providential" type loosely follow the Reformed distinction between general and special providence. General providence entails the overall upholding of creation by God for the good of its inhabitants. God watches over creation and governs it invisibly. Therefore, the effects of general providence are not usually felt as long as a sense of order and overall good is registered. In sports language, this kind of soft providence is relied upon with petitions for safety on the field, strength to persevere, and a sense of peace to counter the violent nature of the game. Denver Broncos defensive lineman Domata Piko states it thusly, "I always ask God before the game and I ask him to give me the strength that he gave to Samson to defeat the Philistines, and I say give me the courage that you gave Daniel when he faced the Lions. I want God's strength out

\footnotetext{
Curry has been writing this verse on the outside of his shoe since college and has commented on the practice.

Tebow used to write chapter and verse on his eye black under his eyes during his football-playing college career, but that practice is disallowed at the professional level.
} 
there." For Piko, God is intervening softly by providing strength and courage that presumably would be lessened in the absence of this gift.

By definition, providence, whether hard or soft, involves an intervening God. According to the dictates of soft providence, an injury-free game may serve as evidence of the kind of divine intervention that is at work. Though if injuries occur, rarely is God's supposed non-intervention or failure to intervene called out. We can suppose that it is far more onerous to exonerate or credit God within the hard providential model, though. Athletes may publically praise a God who keeps them safe, strong, and faithful with impunity. If a freak injury happens, it is not typically theologized. If strength, resolve, and faith were not present on the field, it is rarely acknowledged as God's failure-it is on the athlete or team.

God is prevented from immersing Godself in the messiness of a football game within the soft providential category but not so in the hard providential mode. This second type of providence involves a God who cares who wins, alters play on the field, and affects outcomes through miraculous intervention. This is a partisan God, not unlike the God of the ancient Israelites, who works through athletes and coaches to achieve the desired end. There is much less distance between human and divine will here as athletes who apply the hard providential type to their expressions are claiming to divine God's will as evinced through plays on the field. Hall of Fame quarterback Kurt Warner communicates the difference between hard and soft providentialism nicely by rejecting the former in favor of the latter:

When you stand up and say, "Thank You, Jesus", they think you are saying, "Thank You for being here. Thank You for moving my arm forward and making the ball go into that guy's hands so that we could score a touchdown and win the game." But, in essence, it is a matter of thanking Him for the opportunity, thanking Him for being there in my life, for being the stronghold, for being the focus and the strength to accomplish all things, to accomplish anything, and to be where I am at, to have gone through everything I have gone through.

(Schuster 2014)

\section{Religious Expression in Black and White}

As noted earlier, Leonard problematizes the absence of the role that history, sociology, economics, and politics play in differential treatment of trash-talk delivered by black and white athletes. The same can be said of religious expressions. If the influence on the content and style of rhetoric are appreciated, then the single standard applied to blacks and whites but written and governed by white norms alone invites scrutiny.

The context for much religious expression emergent out of the African American community is slavery and the institutions established under of Jim Crow law. Slave religion, a syncretistic blend of indigenous African traditions and the slave owners' selective offerings of Christianity, needed to respond to the present oppressive conditions. A bound, obedient body and a muted, circumscribed spirit were required in public for survival under slavery. But a body that could be made free through the innervation of the Holy Spirit was a body that stood in opposition to its status on the plantation provided brief, though powerful, refuge.

The spirit's manifestation was corporeal and often wild. W.E.B. DuBois describes an early twentieth century Southern revival thusly:

Finally the Frenzy of "Shouting", when the Spirit of the Lord passed by, and, seizing the devotee, made him mad with supernatural joy, was the last essential of Negro religion and the one more devoutly believed in all the rest... And so firm a hold did it have on the Negro, that many generations firmly believed that without this visible manifestation of the God there could be no true communion with the Invisible. (Du Bois and Marable 1999, pp. 120-21)

While DuBois was somewhat skeptical of the metaphysical reality of the Holy Spirit and uncomfortable with the unrestrained gesticulations, Anthony Pinn argues that spirituality is crucial for his definition 
of the "black soul" as made visible through the body. "Possession by the holy gives the poverty stricken body new value, a new level of spiritual beauty that overrides-at least during the period of communitas - the physical realities of life under the status quo" (Pinn 2003, p. 4). Or according to Albert Raboteau, "Prayer, preaching, song, communal support, and especially 'feeling the spirit' refreshed the slaves and consoled them in their times of distress. By imagining their lives in the context of a different future they gained hope in the present" (Raboteau 1980, p. 218). On Pinn's reading of DuBois, "through the shout or frenzy black bodies were transported beyond the confinements of the Veil and placed in communion with that which affirmed their humanity" (Pinn 2003, p. 3). Pinn translates this historic black pneumatology for the contemporary black church.

The contemporary Church seeks to establish blacks as agents of will-with all the accompanying benefits and responsibilities. Christian gatherings orchestrated by the church often serve as a ritual of exorcism so to speak in that they foster a break with status as will-less objects-impoverished forms-and encourage new forms of relationship and interaction premised upon black intentionality and worth. (Pinn 2003, p. 3)

Or the difference between being a slave, where the spirit was necessary to construct a new free body, and a legally free, but still oppressed African American citizen is that the spirit is galvanizing the will. The black body still endures the white gaze and bodily maltreatment, but the spirit, in conjunction with the will, enables the body's navigation and negotiation in a white world.

This, albeit brief and incomplete, description of the historical and social context of this strand of African American theology can assist us in making sense of the use of hard providential language by black athletes today. If God, whether understood as the Holy Spirit or otherwise, has been employed to reimagine the black body as free, willful, and responsible, it should come as no surprise that this understanding permeates the world of professional football, which is $70 \%$ black. With black bodies risking brain or bodily injury that could end a career (and a paycheck ${ }^{3}$ ) within a milieu of exclusive white ownership of teams and vast majority of white fans, the claim that the supernatural works its way through a natural body towards success exhibits an internal logic. When survival, both on the field and in economic terms, is determined by performance, it is no wonder that God is sometimes given credit for exemplary performance. Triumph is experienced as freedom not wholly unlike the kind experienced within the confines of the black church.

Whites have largely enjoyed the luxury of not having to call on God or the Holy Spirit to reconfigure their bodies in a way that enables the overcoming of societal imprisonment or deleterious stereotypes. God can be conveniently called on to maintain the status quo. Yes, whites, particularly in the South and Appalachian regions, have espoused a similar interpretation of the workings of the Holy Spirit and expressed it with bodily flailing and glossolalia (and have likewise been dismissed by the mainstream). Yet these groups possess the skin pigmentation that solicits judgement of their parochial, "backward" culture without the threat of political punishment for holding such beliefs. African Americans who hold to a relatively similar doctrine and exhibition are doubly punished.

The conventional means of maintaining the political status quo while remaining staunchly Christian for whites has meant trusting in God's soft providence. This way, the sustenance of the "worldly" state of affairs can be comfortably aligned with God's intervention. When that state of affairs is disrupted, it is usually the reflex of the people whose status is at risk to stifle the disruption by sidelining it rhetorically at best, removing it at worst. Granted, the means to preserve social order have changed over time as society has changed. Yet the habit of disciplining the speech, presentation, and actions of African Americans by the white majority dies hard. It is with this in mind that we turn

3 Unlike the NBA, MLB, and NHL, the NFL does not guarantee the terms of any contract with a player. Injury or poor performance (or other considerations) is grounds for immediate severance of the contract with the player, no matter the length of time or amount of money "promised" under the original contract. See https://www.economist.com/the-economistexplains/2018/10/09/how-nfl-contracts-give-players-so-little-power. 
to the several examples of such disciplinary tactics that are applied to language spoken by several African American football players that is of the hard providential type.

\section{God Does Not Care about Football}

On 18 January 2015, the Seattle Seahawks came from behind late in their game to beat the Green Bay Packers in the NFC Championship game. It was particularly stunning that the aforementioned Russell Wilson led the comeback to propel Seattle to its second straight Super Bowl after he had thrown four interceptions earlier in the game. Immediately after the game and on the field with a microphone in his face, Wilson relayed his version of the sequence of events. "That's God setting it up, to make it so dramatic, so rewarding, so special. I've been through a lot in life, and had some ups and downs. It's what's led me to this day." In the Green Bay locker room, the opposing quarterback, Aaron Rodgers, who is white and a devout Christian at the time ${ }^{4}$, was told of Wilson's comments. Understandably upset over the outcome as well as the suggestion that God did this to his team, Rodgers replied, "I don't think God cares a whole lot about the outcome. He cares about the people involved, but I don't think He's a big football fan." When the two teams met up the following season and Green Bay exacted its revenge on the Seahawks, Rodgers snarkily remarked that "I think God was a Packer fan tonight, so he was taking care of us."

David French, in an article in the National Review, uses this back and forth along with other references to God made by athletes to challenge calls by some prominent journalists to get God out of sports. He states, “Rodgers's original distaste for Wilson's comments highlights an underacknowledged truth: the role of God in our personal and professional successes (and failures) is a matter of no small controversy ... " Rodgers' comments comminucate to French how seriously Christians, especially Christian football players, take their theological commitments. He asserts, "to get God out of football, the anti-religious crowd would need to get the football players out of football" (French 2015). French ends with a celebration of the spectrum of religiosity in football as he appreciates both, "Wilson's effusive declaration of his beliefs" and "Rodgers's more understated perspective" without comparing the theology of the two.

While French is likely correct in his assessment of the religious conviction held by a sizable majority of professional football players and hence the impossibility of its vanishing, he misses a crucial point. Rodgers won not only the second game but the rhetorical battle as well. Wilson's hard providential language, that God intervened in the championship game to effect the outcome, is met with a comeback that is more generally accepted in American culture. God has more important things to do than pull the strings on a sporting event, especially as it concerns strings that deliberately cause mistakes only to unveil God's ultimate handiwork. Rodgers then delivers the knockout blow with a sarcastic mimicry of Wilson's interventionism to point out its inconsistency and ludicrousness.

Journalist Dave Zirin is not so equanimous. "When it comes to football, there is no separation between God and the public square. Hearing Aaron Rodgers give a little nationally televised pushback against the idea of a higher power being deeply invested in a football game is as satisfying as it is overdue" (Zirin 2015). Significant for my purposes that I will address shortly, is that neither commentator mentions the race of either quarterback nor its importance in the rhetorical battle.

Another case that displays this kind of back and forth is that of Reggie White, Hall of Fame defensive lineman and ordained minister who passed away in 2004. White has voiced his share of proclamations about God having a direct hand in his career and his play on the field. The "Minister of Defense" certainly talked about glorifying God with his play and used soft providential theology at times to relate God to the game he played. Yet White also spoke as frequently of a partisan God

4 In an interview given in 2017, Rodgers, when he still identified himself as a Christian, replied that he does not affiliate with any religion. http://www.espn.com/espn/feature/story/_/page/enterpriseRodgers/green-bay-packers-qb-aaron-rodgersunmasked-searching. 
who picked his teams to win and intervened to secure the bet. "God intervened in David's fight over Goliath and in Jesus' victory over death", so, White reasoned, how can the football field be off-limits?

White has also credited God with stepping in and guiding his career decisions. He became a free agent in 1993 after playing with the Philadelphia Eagles and repeatedly told the media that God would tell him which team to play for next. He chose Green Bay and recounted the dialogue as such.

I thought, I know God told me to go to San Francisco. What's the deal? And the Lord spoke to me. And when the Lord spoke to me, he said "Let me ask you a question: Where did the head coach, the defensive coordinator and the offensive coordinator all come from before they went to Green Bay?" I said, 'San Francisco?" And he said, "That's the San Francisco I'm talking about!" (Howard 1996)

The disappointed and skeptical Eagles' owner Norman Braman said after White signed with the Packers that Reggie's decision, "wasn't going to be made by a ghetto or by God. It was going to be made for the reason most human beings make decisions today: money." White clapped back, "I just thought, how dare Mr. Braman say that? Money was important, because I needed resources to continue the projects I wanted to do. But how dare he speak for what was in my heart? He doesn't know me. We had dinner. But he never walked down any streets with Reggie White" (Howard 1996). Braman, who is white, attempts to discredit White's story by accusing him of confusion at best (Reggie may think God is talking to him, but it is really Mammon) and lying at worst.

Adding insult to injury, the press had fun with the rumor that it was not God who told White to join the Packers but then coach Mike Holmgren impersonating God. According to the story that Holmgren swears is true, the coach, knowing who the real authority in Reggie's life was, left this message on his answering machine. "Reggie, this is God. Come to Green Bay." Reggie signed with the Packers a short while later. Holmgren's tactic, while clever and effective, betrays a condescension for White's personal belief that God intervenes in the world and speaks to him. That Holmgren could trick White into signing with the Packers by replacing himself for God reveals what he (and the media) thinks of White's theology and its susceptibility for exploitation.

Former Baltimore Ravens' linebacker and Hall of Famer Ray Lewis has similarly relied on hard providential logic. Lewis has unapologetically proclaimed that God does indeed take sides in a football game. When asked, "How does it feel to be a Super Bowl Champion?" Lewis responded, "When God is for you, who can be against you?" This lone statement prompted an Episcopal priest to write an essay disputing Lewis' logic and theology. According to the priest, Lewis is preaching the "Gospel According to Ray without consequence or accountability" that skirts a "fine line between God and Ray ... that not only makes people uncomfortable, it can be dangerous" (Schneck 2013). The danger is cast in theological terms: if there is equation between any human (besides Jesus) and God, then God is subject to the desire of individual humans. God's agency cannot be dragged down and steered in this way.

Lewis' Hall of Fame speech in 2018 faced similar denunciation. Lewis proclaimed that he is God's messenger, that the number he wore (\#52) was God's number, that God healed him of a nasty injury, and that God spoke to him and calmed him while he was dealing with an accusation that he was involved in a double murder. ${ }^{5}$ One journalist called the speech "meandering and mostly meaningless" (Van Bibber 2018). Another called it "frothing madness" and a "desperate, sweaty, rapturous self-exaltation" (Thompson 2018). The thrust of these critiques is that Lewis preaches what God has done for him, but this only runs cover for Ray to talk about himself. Yes, hard providential language suffers little daylight between the divine and its instrument. This can open the speaker up to allegations of self-promotion and egocentrism from secular critics; idolatry and blasphemy from the

5 Lewis was indicted on a murder charge in 2000 for the stabbing deaths of two people that he and two of his friends were seen fighting with. Lewis was given a misdemeanor plea in exchange for pleading guilty to obstructing justice with misleading statements the night of murder. The case remains unsolved. 
religious sort. That Lewis believes that God intervenes in all aspects of his life, including his play on the field, is somehow proof that he is unhinged, narcissistic, and therefore not to be taken seriously.

In one final example, the headline on the cover of Sport Illustrated's 1998 pre-Super Bowl issue read, "Does God Care Who Wins the Super Bowl?" Provocative and outside of the magazine's usual questions posed to its readers, this seemed a good one to ask after hearing from some of the players about to take the field in the upcoming game. Several players from the Denver Broncos, all black with one exception, viewed their win over the Pittsburgh Steelers to earn a trip to the Super Bowl as an act of God. Fullback Howard Griffith elaborated on an important play that he made in the game: "I attribute everything to Him. The Lord allowed me to make that catch." Further, "God directs everything, He already knows the outcome. Kordell (the Steelers' quarterback) didn't go out there to throw those interceptions. The game was already decided before we walked out there." Tight end Dwayne Carswell reflected on two crucial interceptions made by the Broncos: "God could have caused that. He's in everybody's corner, but I guess He decided that we deserved [to win]." And tackle Tony Jones answered the magazine's opening question with a "yes", God cares specifically about the Broncos. "He's been looking out for us the whole season. We've been through some tough storms, but He brought us through. Now we are on our way to San Diego, and we know He is with us." To no surprise, Reggie White, who was playing for the upcoming opposing Packers, opined, "God had a lot to do with this, and I praise God that I had a chance to win one Super Bowl last year and now another."

Interestingly, the article leads with these comments by black athletes and is led the rest of the way by white players, theologians, and religious leaders who proceed to undercut what came before. This second part is set up with loaded questions that goad readers into formalizing expected answers.

Does God take an active interest in the outcome of athletic matches? Did He favor Denver over Pittsburgh or Green Bay over San Francisco? Does a believer on one side of the ball have an advantage over a nonbeliever on the other side of it? Does God even know there is a Super Bowl?

Adam Timmerman, white guard for Green Bay, is given first crack at an answer. "I ask him to keep us from injuries. And I ask for victories: 'God, I want to win so I have an even bigger platform to use for you.' People listen to winners more than they do to losers."

With that from inside the locker room, the article moves outside the lines. Richard J. Wood, dean of the Yale Divinity School, approaches the issue by separating divine omniscience from divine interest. "It doesn't seem to me odd that God would know in detail what happens in football games. What seems to me odd is that God would care." Given the "more important" events going on in the world, "that God has a direct involvement in athletic contests trivializes the whole notion of God's involvement with the world. It is a heresy." Joseph C. Hough, dean of the Vanderbilt Divinity School, damns the thought of God sinking down to the level of football games. It "makes God look immoral and arbitrary. I find that religiously offensive." And former president of Fuller Theological Seminary, Richard Mouw adds,

I think it's very dangerous for us to identify the will of God with a specific win. There may be all kinds of ways in which the outcome of a game could serve God's purpose, but God isn't a Michigan or Notre Dame fan. Football can be a way of serving God, and I think God cares about how people play the game. But I think we have to avoid identifying God with any partisan cause. (Nack 1998)

Those who critically respond to the possibility of God intervening in athletic activity express serious concerns about a God who could and would pick sides, manipulate bodily action on the field, and steer footballs into the right place. The issue put forth in this essay, however, is that these responses are already shielded before they are vented. These rejoinders and the attitude that animate them help reproduce a political theology that has, often unconsciously, disregarded the material body as a site of theological construction. The conviction held by many African Americans, and not by most whites, 
that God works through the bodies that have been treated as merely flesh and continue to be treated as such is ignored.

The double standard is, perhaps, most noticeable in the way in which Tim Tebow was treated during his rise in the 2011 season as quarterback of the Denver Broncos. Predictably, Tebow has been trained in the soft providential mode of thinking and speaking about God, especially as it relates to sports. What makes him unique in the world of the NFL that is stocked with obvious talent is that he has been widely regarded as bereft of the that same talent needed to be successful in the NFL. His lack of a job in the NFL heretofore has seemingly borne this out. Still, during the 2011 season, Tebow quarterbacked a team with midseason woes through last minute victories to a playoff win. His statistics during this run belied the win total-he was subpar statistically, but the Broncos still won games. This discrepancy prompted journalists across the spectrum to entertain the possibility that God was intervening in these games. Wary of fully committing to divine intervention in Tebow's achievements, some mainstream journalists still had no problem throwing around the word "miraculous" to describe what occurred in these games. His string of victories were "downright eerie" (Schefter 2012) for instance. Some were even led to question their atheism (Engber 2011). And Harvard researchers studied whether Tebow's wins were indeed miraculous based on statistical anomalies that dogged his history as a professional quarterback and these wins that followed. We can only assume that the word "miracle" was deployed in this study with a certain "tongue-in-cheek" attitude. But the mere fact that the term was used indicates the need for non-scientific terminology that may gesture towards the possibility of supernatural intervention in their supposed objective explanation (Bruce and Mooney 2013).

Miracles evince hard providentialism in unambiguous terms. But Tebow has consistently rejected any suggestion that God works in this way, despite the cacophony around him arguing otherwise. As he writes in his autobiography, "God gave us specific talents", "God receives joy when he sees me doing that with the skills he blessed me with", and that, "God has a plan for our lives" (Tebow and Whitaker 2011, p. 134). This is soft providential language to be sure, and Tebow is careful to walk up to the line that separates the hard and soft type, but he never steps over it.

I know it sounds dumb to be praying over a football game ... I'm not sure God is into who wins or loses-He probably is more concerned with what you do in the process and what you will do with either result, to glorify Him and change the world by hopefully impacting one life. (Tebow and Whitaker 2011, p. 116)

To wit, after Tebow was credited by some for performing a miracle by touching and praying over a child who had a seizure in the stands, he demurred. "As far as me and miracles, no. But in the God that we serve, yeah, I do believe in miracles. I don't know what the situation was, but I know that the God that I get to serve is the God that always performs miracles in people's lives every day, all the time" (Peter 2016).

While Tebow's genuflecting on the field after a touchdown and giving praise to Jesus Christ immediately after games has been met with indignation by fans and the media alike wishing athletes remain silent on such matters, his theology has not faced the same judgment countenanced by black athletes for relying on providential language. Tebow's glorification language bleeds freely into his soft providential stance that God does intervene in football games by furnishing him with the strength to compete. Yet that providentialism is softened even further by subsuming into the glorification model. God's omnipotence and omnipresence are given credence out of deference, but a kind of theological guilt prevents Tebow and other athletes from taking their theology to its logical conclusion: if God prevents injuries on the field and strengthens you to win the game, why does God not also affect the outcome of the game, given what God supposedly cares about? By (perhaps artificially) insulating God from the need to care about the nitty-gritty of the game itself and who wins that game yet still maintaining that God does intervene in the game in a general sense, Tebow is able to walk down the established path that "correctly" conjoins God and sports. 
$\mathrm{He}$, like other white athletes, has no historical memory of having their body owned, depreciated, or feared. Therefore, his God has never been called on to act through his body; to redeem and purify it. God may bequeath Tebow disembodied gifts such as faith, talent, grit, strength, and a platform for evangelism but apparently never gives him first downs, touchdowns, or wins. His career and the reaction to it demonstrates the double standard applied to black and white athletes regards their religious expressions. God intervenes within the frameworks of both soft and hard providentialism, yet one type is deemed appropriate; the other is not. One involves God in all of life, sport included, though is unaware of the role that race plays in inoculating its speech from criticism; the other unabashedly involves God in minute bodily movements during a game and emerges out of the need to survive in a world and sport controlled by whites, yet is criticized nonetheless.

\section{Conclusions}

I have attempted to call attention to a racially based double standard as it has been applied to religious expressions of football players. Akin to the uneven treatment of trash-talkers in the NFL, hard providentialism that undergirds some religious talk by black football players is routinely ignored or deemed illegitimate while the soft providential language of white athletes and some black athletes gets a pass. A part of what makes this double standard so pernicious is that much of the discourse involving such talk is trafficked in the abstract that exists above the concrete historical and political forces that have given voice, and therefore communally justified hard providential theology within African American religious communities. Indeed, the authority required in order to contend that God does not care about football is granted only when the material sources of the speaker's theology are ignored. Because account is rarely taken by these cultured despisers of the historical and political factors that validate and absolutize their own critique (and allow a disregard of the sources of that which they critique) and protect it from the accusation that they use a double standard, their rules that regulate the relationship between God-talk and sport abide. Without entering into the debate of God's "proper "relationship to action on the field, this essay has ideally foregrounded the role that race plays in creating and sustaining such a double standard. Leaving it in the background or removing it from the frame altogether facilitates the deleterious perpetuation of the myth that we live in a post-racial society and that sport is the ultimate "colorblind meritocracy."

Funding: This research received no external funding.

Conflicts of Interest: The author declares no conflict of interest.

\section{References}

Blazer, Annie. 2015. Playing for God: Evangelical Women and the Unitended Consequences of Sports Ministry. New York: New York University Press.

Bruce, Chris, and Andrew Mooney. 2013. The Harvard Sports Analysis Collective. Available online: http://harvardsportsanalysis.org/2011/11/a-statistical-analysis-of-the-miracles-of-tim-tebow/ (accessed on 9 January 2019).

Buehring, Tom. 2019. I Think About Jesus Christ': These 4 NFL Players Are Keeping Faith at the Forefront of This Super Bowl. CBN News. February 3. Available online: https://www1.cbn.com/cbnnews/entertainment/2019/february/ithink-about-jesus-christ-these-4-nfl-players-are-keeping-faith-at-the-forefront-of-this-super-bowl (accessed on 3 March 2019).

Cox, Daniel, and Robert P. Jones. 2017. One-Quarter Say God Will Determine the Super Bowl's Winner-But Nearly Half Say God Rewards Devout Athletes. PPRI. January 30. Available online: https:/www.prri.org/ research/poll-super-bowl-women-sports-god-athletes-marijuana/ (accessed on 16 November 2018).

Curtis, Bryan. 2017. The Pretty Good Life of Tony Romo. The Ringer. March 8. Available online: https://www. theringer.com/2017/3/8/16041308/tony-romo-release-dallas-cowboys-dak-prescott-16e63faec1fb (accessed on 18 February 2019). 
Du Bois, William Edward Burghardt, and Manning Marable. 1999. The Souls of Black Folk. New York: W. W. Norton and Company.

Engber, Daniel. 2011. Tim Tebow 2011: The Broncos Quarterback Is Making Me Question My Atheism. Slate. December 5. Available online: https://slate.com/culture/2011/12/tim-tebow-2011-the-broncos-quarterback-ismaking-me-question-my-atheism.html (accessed on 18 February 2019).

French, David. 2015. The Ridiculous Movement to Take God Out of Football. National Review. September 22. Available online: https://www.nationalreview.com/2015/09/god-football-atheist-activists/ (accessed on 11 November 2018).

Hoffman, Shirl J. 1992. Evangelicalism and the Revitalization of Religious Ritual in Sport. In Sport and Religion. Edited by Shirl J. Hoffman. Champaign: Human Kinetics.

Howard, Johnette. 1996. Up from the Ashes Packer Reggie White Preaches that God Can Raise a Man to the Super Bowl and a Church from Ruins. Sports Illustrated. September 2. Available online: https://www.si.com/vault/1996/09/02/217042/up-from-the-ashes-packer-reggie-white-preaches-thatgod-can-raise-a-man-to-the-super-bowl-and-a-church-from-ruins (accessed on 17 October 2018).

Klemko, Robert. 2017. Available online: https://www.si.com/mmqb/2017/06/15/nfl-team-survey-playerupbringings-race-class-2016-election (accessed on 8 May 2019).

Krattenmaker, Tom. 2010. Onward Christian Athletes: Turning Ballparks into Pulpits and Players into Preachers. Lantham: Rowman \& Littlefield.

Leonard, David J. 2017. Playing While White: Priviledge and Power on and off the Field. Seattle: University of Washington Press.

Nack, William. 1998. Does God Care Who Wins the Super Bowl? VAULT. January 26. Available online: https:/www.si.com/vault/1998/01/26/238058/does-god-care-who-wins-the-super-bowlmany-packers-and-broncos-think-the-lord-will-decide-the-outcome-theologians-beg-to-differ (accessed on 14 November 2018).

Parke, Caleb. 2019. Russell Wilson Gives Glory to God after Becoming NFL's Highest-Paid Player. Fox News. April 16. Available online: https://www.foxnews.com/faith-values/russell-wilson-gives-glory-to-god-afterbecoming-nfls-highest-paid-player (accessed on 22 June 2019).

Peter, Josh. 2016. Tim Tebow on Miracles, Helping Arizona Fall League Fan in Need. USA Today. October 13. Available online: https://www.usatoday.com/story/sports/mlb/mets/2016/10/12/tim-tebow-on-helpingarizona-fall-league-fan/91980992/ (accessed on 27 October 2018).

Pinn, Anthony B. 2003. DuBois' Souls: Thoughts on "Veiled Bodies and the Study of Black Religion". The North Star: A Journal of African American Religious History 6: 1-5.

Raboteau, Albert J. 1980. Slave Religion: The "Invisible Instition" in the Antebellum South. New York: Oxford University Press.

Schefter, Adam. 2012. Available online: https://www.espn.com/nfl/story/_/page/10spot-divisional/tim-tebowphenomenon-gets-eerie--adam-schefter-10-spot (accessed on 16 October 2018).

Schneck, Tim. 2013. The Theology of Ray Lewis. Huffington Post. February 2. Available online: https: //www.huffpost.com/entry/the-theology-of-ray-lewis_b_2617107 (accessed on 14 January 2019).

Schuster, Shawn. 2014. Former NFL Star Kurt Warner Catches Criticism for His Christian Beliefs, Told He Should be 'Lined up and Shot'. The Gospel Herald. November 10. Available online: https://www.gospelherald.com/articles/53130/20141110/former-nfl-star-kurt-warnercatches-criticism-for-his-beliefs-told-he-should-be-lined-up-and-shot.htm (accessed on 22 March 2019).

Tebow, Tim, and Nathan Whitaker. 2011. Tim Tebow: Through My Eyes. New York: HarperCollins.

Thompson, Chris. 2018. Ray LewisThe Theology of Ray Lewiss Hall Of Fame Speech Was Actual Frothing Madness. Deadspin. August 8. Available online: https://deadspin.com/ray-lewiss-hall-of-fame-speech-wasactual-frothing-madn-1828116271 (accessed on 16 November 2018).

Van Bibber, Ryan. 2018. What the hell is Ray Lewis Talking About? SBNation. August 5. Available online: https://www.sbnation.com/nfl/2018/8/4/17630430/ray-lewis-hall-of-fame-speech-ravens-what-ishe-talking-about (accessed on 14 November 2018). 
Zirin, Dave. 2015. The Age Gap in Religion around the World. The Nation. September 21. Available online: https://www.thenation.com/article/getting-god-out-of-football/ (accessed on 3 November 2018).

The Age Gap in Religion around the World. 2018. Available online: https://www.pewforum.org/2018/06/13/theage-gap-in-religion-around-the-world/ (accessed on 4 April 2019).

(C) 2019 by the author. Licensee MDPI, Basel, Switzerland. This article is an open access article distributed under the terms and conditions of the Creative Commons Attribution (CC BY) license (http://creativecommons.org/licenses/by/4.0/). 